\title{
Use of GIS and Remote Sensing Technology as a Decision Support Tool in Flood Disaster Management: The Case of Southeast Louisiana, USA
}

\author{
Yaw A. Twumasi ${ }^{1}$, Edmund C. Merem ${ }^{2}$, John B. Namwamba ${ }^{1}$, Ronald Okwemba1, \\ Tomas Ayala-Silva ${ }^{3}$, Kamran Abdollahi', Onyumbe E. Ben Lukongo ${ }^{4}$, Joshua Tate ${ }^{1}$, \\ Kellyn La Cour-Conant ${ }^{1}$, Caroline 0. Akinrinwoye ${ }^{1}$
}

\footnotetext{
${ }^{1}$ Department of Urban Forestry and Natural Resources, Southern University and A\&M College, Fisher Hall, Baton Rouge, Louisiana, USA

${ }^{2}$ Department of Urban and Regional Planning, Jackson State University, Jackson, Mississippi, USA

${ }^{3}$ USDA-ARS Tropical Agriculture Research Station, Mayaguez, Puerto Rico

${ }^{4}$ Department of Public Policy, Southern University and A\&M College, Nelson Mandela College of Government and Social Sciences, Baton Rouge, Louisiana, USA

Email: *yaw.twumasi@subr.edu, *yaw.twumasi@gmail.com
}

How to cite this paper: Twumasi, Y.A., Merem, E.C., Namwamba, J.B., Okwemba, R., Ayala-Silva, T., Abdollahi, K., Lukongo, O.E.B., Tate, J., La Cour-Conant, K. and Akinrinwoye, C.O. (2020) Use of GIS and Remote Sensing Technology as a Decision Support Tool in Flood Disaster Management: The Case of Southeast Louisiana, USA. Journal of Geographic Information System, 12, 141-157. https://doi.org/10.4236/jgis.2020.122009

Received: January 21, 2020

Accepted: April 27, 2020

Published: April 30, 2020

Copyright $\odot 2020$ by author(s) and Scientific Research Publishing Inc. This work is licensed under the Creative Commons Attribution International License (CC BY 4.0).

http://creativecommons.org/licenses/by/4.0/ (c) (i) Open Access

\begin{abstract}
The primary objective of this paper was to identify flood-prone areas in Southeast of Louisiana to help decision-makers to develop appropriate adaptation strategies and flood prediction, and mitigation of the effects on the community. In doing so, the paper uses satellite remote sensing and Geographic Information System (GIS) data for this purpose. Elevation data was obtained from the National Elevation Dataset (NED) produced by the United States Geological Survey (USGS) seamless data warehouse. Satellite data was also acquired from USGS Earth explorer website. Topographical information on runoff characteristics such as slope, aspect and the digital elevation model was generated. Grid interpolation TIN (triangulated irregular network) was carried from the digital elevation model (DEM) to create slope map. Image Drape was performed using ERDAS IMAGINE Virtual GIS. The output image was then draped over the NED elevation data for visualization purposes with vertical exaggeration of 16 feet. Results of the study revealed that majority of the study area lies in low-lying and very low-lying terrain below sea level. Policy recommendation in the form of the need to design and build a comprehensive Regional Information Systems (RIS) in the form of periodic inventorying, monitoring and evaluation with full support of the govern-
\end{abstract}


ments was made for the study area.

\section{Keywords}

GIS, Remote Sensing, Flood Disaster Management, Regional Information Systems (RIS), Southeast Louisiana

\section{Introduction}

Flooding is one of the major environmental problems facing the world. In recent years flooding has claimed thousands of lives and made hundreds of thousands of people homeless and caused several hundred billion dollars in economic losses. The severity of this problem has attracted the attention of the world community in recent years. In an attempt to prevent and lessen these disasters, the First World Conference on Natural Disasters was convened by United Nations' General Assembly in Yokohama, Japan from 23 to 27 May 1994 with the goal and objectives among others geared towards disaster prevention, preparedness and mitigation [1]. Yokohama conference led to follow-up conferences in Kobe (2nd) on 18-22 January 2005 and in Sendai (3rd) on 14-18 March 2015. These conferences were coordinated by the United Nations General Assembly and the United Nations Office for Disaster Risk Reduction (UNISDR). The main objectives of the Second conference in Kobe were to find ways to reduce the toll of disasters through preparation, and ultimately to reduce human casualties. In Kobe, Hyogo Framework for Action (HFA) from (2005-2015) was introduced with overall goal of building the resilience of Nations and Communities to Disasters [1]. The (HFA) was the first plan to explain, describe and detail the work required from all different sectors and actors to reduce disaster losses. The Third UN World conference adopted the Sendai Declaration and Framework for Disaster Risk Reduction 2015-2030. The main aim of the conference was to update the landmark agreement reached in (HFA). The conference brought together all the stakeholders including government and civil society leaders from around the globe to discuss and strategized effective ways to compact and prepare for impact of disasters, and to agree on an updated global response framework [1] [2].

In the United States, more recent data shows that among natural hazards, flood is one of the most common and costliest disasters facing the nation. This is shown by the increases in natural hazards-related spending in the last two decades. Historical data show that U.S. spent $\$ 62$ billion on disaster relief in fiscal years 2011 and 2012 [3]. According to the National Oceanic and Atmospheric Administration's (NOAA's) 2018 Flood Damage Data report posted on their website; U.S. spent in 2014 about $\$ 2.8$ billion on flood related damages [4]. Recent Reuters report by Blake Brittain, indicated that weather and climate-related disasters cost the United States a record \$306 billion in 2017 [5]. Also, a report by NOAA indicated that the first three months of 2018, U.S. spent 
3 billion-dollar on geohazards-related disasters [6].

\section{Identification of Flood-Prone Areas Using GIS and Remote Sensing}

Geospatial information is essential for an effective and quick response to emergency management, especially flooding. GIS and remote sensing technologies play an important role in understanding various disasters, their outcomes, and the damage they could inflict on a given area [7] [8] [9]. Early work by Twumasi and Asomani-Boateng [10] and Twumasi et al. [11] used GIS and other technologies to investigate urban flood zones in Accra, Ghana. Results of the study revealed notable flood risk zones and watercourses. Twumasi et al. [8] have used remote sensing and GIS technology to design an appropriate coastal database in six counties in Southern Mississippi. Results revealed that a greater part of the three counties along the coast lies less than 10 meters above mean sea level with exposure to coastal flooding disaster vulnerability. Twumasi et al. [12] employed remote sensing and GIS data to visualize the impact of climate change caused by flooding in the Southern African region in order to assist decision makers' plans for future occurrences. The study used Digital Elevation Model (DEM), temporal Landsat Enhanced Thematic Mapper Plus (ETM+) and Moderate Resolution Imaging Spectroradiometer (MODIS) satellites data obtained from the United States Geological Survey (USGS) and NASA's Earth Observatory website. Results of the study revealed notable damages to social and natural environments as well as flood risk zones and watercourses in the study area. Other studies by Cox and James [13] used ArcGIS 3D Analyst extension's ArcScene application software to create a 3D Visualization model that showed what parts of City of Davenport, Iowa would be submerged at deferent flood stages. Results of the study helped the city staff and council to visualize data about how floodwater could affect specific areas of the city at any flood stage. In the Izmir province of Turkey, Ozkan and Tarhan [14] used Shuttle Radar Topographic Mission (SRTM) Digital elevation model (DEM) data to predict potential flood hazard areas. Indeed, several research studies using GIS and Remote Sensing to identify flood-prone areas have been reported [15]-[20]. Isma'il and Saanyol [21] coupled remote sensing and DEM data to map Kaduna River flood-prone areas using high resolution imagery obtained from Google Earth. Flood risk modeling using remote sensing and GIS has also gained considerable attention. For example, Lanza and Conti [22] have used remote sensing data to forecast flood hazard. Dang and Kumar [23] utilized remote sensing techniques combined with Geographic Information Systems-based hydrological modelling to identify flood risk in Ho Chi Minh City, Vietnam. Their study showed that rainfall-induced flood was not a serious problem with the flood depth of $2-10 \mathrm{~cm}$ while tidal flood was a substantial issue with $10-100 \mathrm{~cm}$ flood depths. The impacts of flooding will extend beyond relocation and food shortages and in the process, negatively affect local and national economies. Therefore, in order to reduce the 
cost and impacts associated with natural hazards such as flooding, it is necessary to investigate and understand the areas vulnerable to flooding. Perhaps the use of geographical information systems (GIS) and remote sensing technologies could assist policy makers in sustainable planning and management. Review of literature in the area shows that, there is a gap in information and knowledge on the use of spatial technology as decision support tool to aid flood management. It is therefore important to identify the areas vulnerable to flooding and determine the associated response. Thus, the primary objective of this paper was to identify flood-prone areas in the Southeast of Louisiana using GIS and remote sensing techniques. It is anticipated that the results of this study will be used to guide management and provide parishes with tools needed to plan for the predicted increase in flood events and mitigation of the effects on the community.

\section{Methodology}

\subsection{The Study Area}

The focus areas of this study were eleven parishes of Southeast Louisiana. These parishes are Washington, Tangipahoa, St. Tammany, St. John the Baptist, Orleans, St. Charles, St. Bernard, Jefferson, La Fourche, Plaquemines, and Terrebonne (Figure 1).

In the last two decades, the study area has experienced tremendous natural disasters which are related to flooding. Data from National Hurricane Center in Table 1 and Table 2 show the area has been impacted by tropical cyclones and is very vulnerable to strikes by major hurricanes. In 2005, Hurricane Katrina floods cost billions of dollars, destroying businesses, homes, and taking many lives (Table 1). In 2012 alone, the area and other parts of the state experienced more than 15 different storms between May and October destroying millions of Dollars'

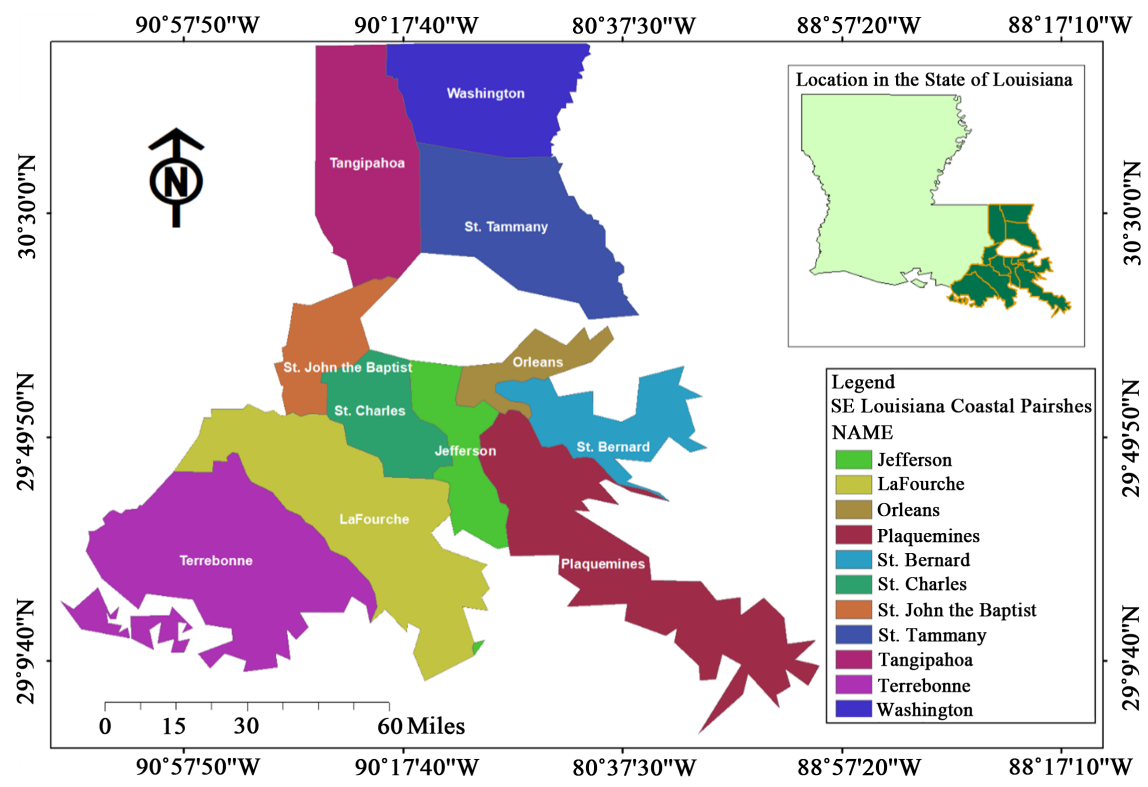

Figure 1. The study area. 
Table 1. Chronology of Louisiana tropical hurricanes and storms and their impacts (1997-2005) [7] [25] [26] [27] [28].

\begin{tabular}{|c|c|c|}
\hline Year & Name & Impact \\
\hline 1992 & $\begin{array}{l}\text { Hurricane Andrew, Cat. } 4 \text { across Florida, } \\
\text { Cat. } 3 \text { upon landfall in Louisiana }\end{array}$ & $\begin{array}{l}\text { 17-foot storm surge in Florida, } 8 \text {-foot } \\
\text { storm tide in Louisiana, } 23 \text { deaths } \\
\text { nationwide, } \$ 26.5 \text { billion in damages } \\
\text { nationwide; } \$ 1 \text { billion in Louisiana and } \\
\$ 25.5 \text { billion in Florida }\end{array}$ \\
\hline 1997 & $\begin{array}{l}\text { Hurricane Danny, Cat. 1, Landfall in } \\
\text { Louisiana, Tropical Storm over Florida }\end{array}$ & $\begin{array}{l}4 \text { deaths nationwide, } \$ 100 \text { million in total } \\
\text { damages nationally }\end{array}$ \\
\hline 1998 & $\begin{array}{l}\text { Tropical Storm Hermine, } \\
\text { Landfall in Louisiana }\end{array}$ & No information \\
\hline 2001 & $\begin{array}{l}\text { Tropical Storm Allison, } \\
\text { Landfall in Louisiana }\end{array}$ & $\begin{array}{l}\text { Excessive rain-up to } 30 \text { inches in places, } \\
23 \text { tornadoes across the Southeast, } \\
41 \text { deaths nationwide. } \$ 5 \text { billion in damages } \\
\text { nationwide }\end{array}$ \\
\hline 2002 & $\begin{array}{l}\text { Tropical Storm Bertha, } \\
\text { Landfall in Louisiana }\end{array}$ & $\begin{array}{l}\text { 3- to } 4 \text {-foot storm tides, Heavy rains; } \\
3 \text { - } 6 \text { inches across Louisiana, No monetary } \\
\text { damage figures available }\end{array}$ \\
\hline 2002 & $\begin{array}{l}\text { Tropical Storm Hanna, } \\
\text { Landfall in Louisiana }\end{array}$ & $\begin{array}{l}5-10 \text { inches of rain across southeast states, } \\
\$ 20 \text { million in damages nationwide }\end{array}$ \\
\hline 2002 & $\begin{array}{l}\text { Tropical Storm Bertha, } \\
\text { Landfall in Louisiana }\end{array}$ & $\begin{array}{l}\text { 3- to } 4 \text {-foot storm tides, Heavy rains; } \\
3 \text { - } 6 \text { inches across Louisiana, No monetary } \\
\text { damage figures available }\end{array}$ \\
\hline 2002 & $\begin{array}{l}\text { Tropical Storm Hanna, } \\
\text { Landfall in Louisiana }\end{array}$ & $\begin{array}{l}5-10 \text { inches of rain across southeast states, } \\
\$ 20 \text { million in damages nationwide }\end{array}$ \\
\hline 2003 & $\begin{array}{l}\text { Tropical Storm Bill, } \\
\text { Land-fall in Louisiana }\end{array}$ & $\begin{array}{l}4 \text { deaths, } \$ 50 \text { million in damages } \\
\text { nationwide }\end{array}$ \\
\hline 2004 & $\begin{array}{l}\text { Hurricane Ivan, Cat. } 4 \text {, } \\
\text { Tropical storm across East Coast that } \\
\text { looped back to Louisiana }\end{array}$ & $\begin{array}{l}10 \text { - to } 15 \text {-foot storm surge, } 10-15 \text { inches } \\
\text { of rain, } 25 \text { deaths in the United States, } \\
\$ 14.2 \text { billion in damages nation }\end{array}$ \\
\hline 2004 & Tropical Storm Matthew & $\begin{array}{l}\text { Heavy rains, } 6 \text {-foot storm surge, } \\
\text { No information on damages available }\end{array}$ \\
\hline 2005 & $\begin{array}{l}\text { Hurricane Cindy, Cat. 1, } \\
\text { Landfall in Louisiana }\end{array}$ & $\begin{array}{l}\text { 4- to } 6 \text {-foot storm surge, } 33 \text { tornadoes } \\
\text { across the east as system moved north, } \\
\text { Heavy rains across all eastern states, } 1 \text { death, } \\
\$ 320 \text { million in damages nationwide }\end{array}$ \\
\hline 2005 & $\begin{array}{l}\text { Hurricane Katrina, Cat. } 5 \text {, } \\
\text { Cat. } 1 \text { across Florida, Cat. } 3 \text { in Louisiana }\end{array}$ & $\begin{array}{l}\text { 10- to } 20 \text {-foot storm surge in Louisiana; } \\
\text { storm surge penetrated } 6 \text { miles inland in } \\
\text { some locations of Louisiana, } 28 \text {-foot storm } \\
\text { tide reported in Mississippi, } 11 \text { - } 14 \text { inches of } \\
\text { rain in Dade County, Florida; } 8 \text { - } 10 \text { inches } \\
\text { across Louisiana, } 33 \text { reported tornadoes, } \\
1336 \text { known deaths nationwide, } \\
\$ 40 \text { - } 120 \text { billion in damages nation-wide }\end{array}$ \\
\hline 2005 & $\begin{array}{l}\text { Hurricane Rita, Cat. } 5 \text {, } \\
\text { Cat. } 3 \text { before landfall in Louisiana }\end{array}$ & $\begin{array}{l}\text { 4- to } 7 \text {-foot storm surge (gauge); } 8 \text { - to } \\
12 \text {-foot storm surge (visual evidence); } \\
4 \text { - to } 5 \text {-foot storm surge in Florida Keys, } \\
90 \text { tornadoes, } 7 \text { deaths } \$ 10 \text { billion in damages } \\
\text { nationwide }\end{array}$ \\
\hline 2005 & $\begin{array}{l}\text { Tropical Storm Tammy, } \\
\text { Landfall in Florida }\end{array}$ & $\begin{array}{l}\text { 2- to } 4 \text {-foot storm surge, } 3 \text { - } 5 \text { inches of rain, } \\
\$ 25 \text { million in damages nation-wide }\end{array}$ \\
\hline
\end{tabular}


Table 2. 2012 Atlantic hurricane season statistics [25] [29].

\begin{tabular}{|c|c|c|c|c|c|c|}
\hline $\begin{array}{l}\text { Storm } \\
\text { Name }\end{array}$ & Class $^{\mathrm{a}}$ & Dates $^{\mathrm{b}}$ & $\begin{array}{l}\text { Max. } \\
\text { Winds } \\
(k t)\end{array}$ & $\begin{array}{c}\text { Min. } \\
\text { Pressure } \\
(\mathrm{mb})\end{array}$ & Deaths & $\begin{array}{c}\text { U.S. } \\
\text { Damage } \\
\text { (\$ million) }\end{array}$ \\
\hline Alberto & TS & May $19-22$ & 50 & 995 & & \\
\hline Beryl & TS & May 26-30 & 60 & 992 & 1 & \\
\hline Chris & $\mathrm{H}$ & June $18-22$ & 75 & 974 & & \\
\hline Debby & TS & June $23-27$ & 55 & 990 & 5 & 250 \\
\hline Ernesto & $\mathrm{H}$ & August $1-10$ & 85 & 973 & 7 & \\
\hline Florence & TS & August 3-6 & 50 & 1002 & & \\
\hline Gordon & $\mathrm{H}$ & August 15-20 & 95 & 965 & & \\
\hline Helene & TS & August 9-18 & 40 & 1004 & & \\
\hline Isaac & $\mathrm{H}$ & August 21-September 1 & 70 & 965 & 34 & 2350 \\
\hline Joyce & TS & August 22-24 & 35 & 1006 & & \\
\hline Kirk & $\mathrm{H}$ & August 28-September 2 & 90 & 970 & & \\
\hline Leslie & $\mathrm{H}$ & August 30-September 11 & 70 & 968 & & \\
\hline Michael & MH & September 3-11 & 100 & 964 & & \\
\hline Nadine & $\mathrm{H}$ & September 10-October 3 & 80 & 978 & & \\
\hline Oscar & TS & October 3-5 & 45 & 994 & & \\
\hline Patty & TS & October 11-13 & 40 & 1005 & & \\
\hline Rafael & $\mathrm{H}$ & October $12-17$ & 80 & 969 & 1 & \\
\hline Sandy & MH & October 22-29 & 100 & 940 & 147 & 50000 \\
\hline Tony & TS & October 22-25 & 45 & 1000 & & \\
\hline
\end{tabular}

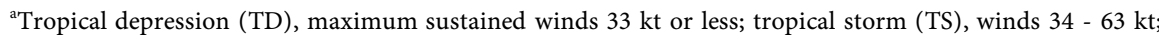
hurricane $(\mathrm{H})$, winds 64 - $95 \mathrm{kt}$; major hurricane $(\mathrm{MH})$, winds $96 \mathrm{kt}$ or higher; ${ }^{\mathrm{b}}$ Dates begin at 0000 UTC and include all tropical and subtropical cyclone stages; non-tropical stages are excluded.

worth of property and loss of lives (Table 1). Casualty tally from Table 1 shows 195 deaths related to hurricanes in 2012 alone with Sandy being the highest. The area, receives rainfall throughout the year particularly during the winter months. The area, like the rest of Louisiana, experiences hot and humid summer, with elevated temperatures from mid-June to mid-September averaging $90^{\circ} \mathrm{C}\left(32^{\circ} \mathrm{C}\right)$ or more and overnight lows averaging above $70^{\circ} \mathrm{F}\left(22^{\circ} \mathrm{C}\right)$ [7]). Due to low elevation, most areas get flooded during hurricane and tropical storms [24].

Recent floods in August 2016 and July 2019 destroyed parts of surrounding coastal areas in southeast and southern Louisiana [30]. In early July 2019, Hurricane Barry caused flood in many parts of Southeast Louisiana. Low lying areas such Orleans, St. Bernard and Plaquemines experienced heavy flooding. Excessive rainfall led to widespread flooding in southeast and southern Louisiana, as rivers swelled high above their banks. Representative samples of these floods are shown below in Figures 2-5. 


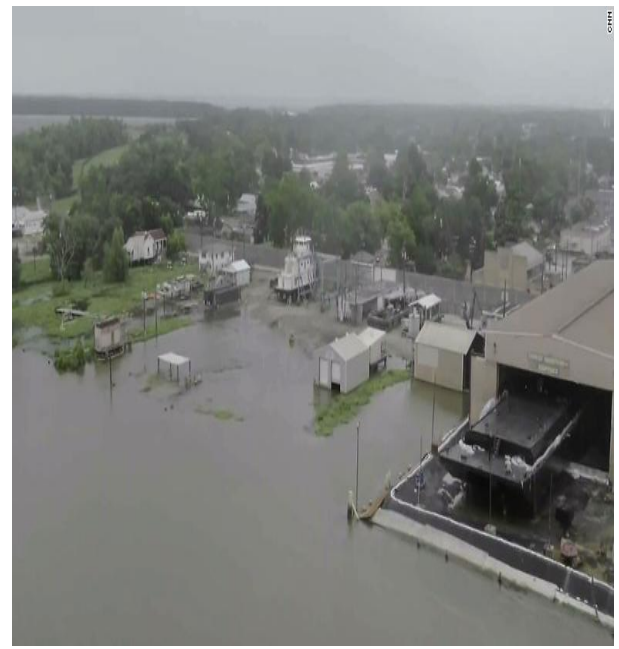

Figure 2. Flooded road near Lake Pontchartrain, LA: Photo Courtesy of CNN [31].

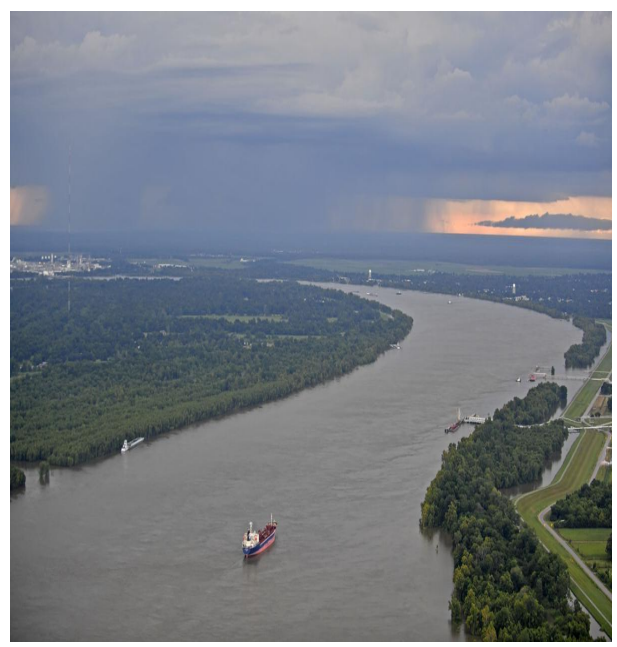

Figure 3. Swollen Mississippi river caused by intense rainfall: Photo Courtesy of the advocate [32].

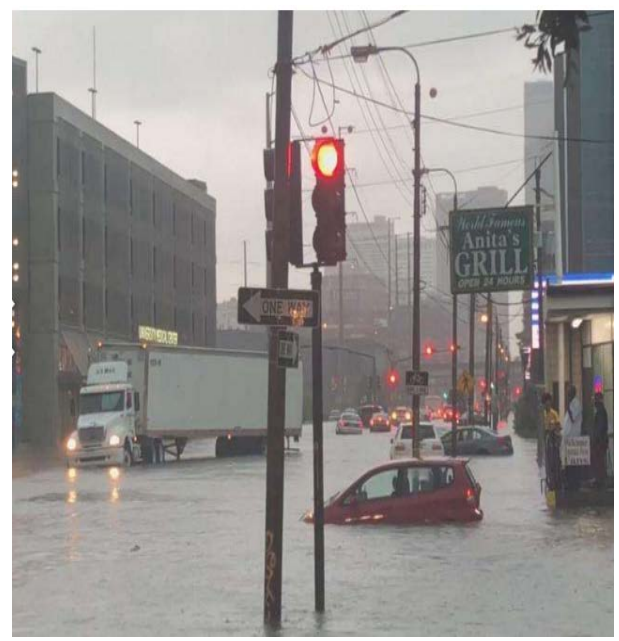

Figure 4. Inundated areas in downtown by New Orleans caused hurricane Barry: Image Courtesy of San Francisco Gate [33]. 


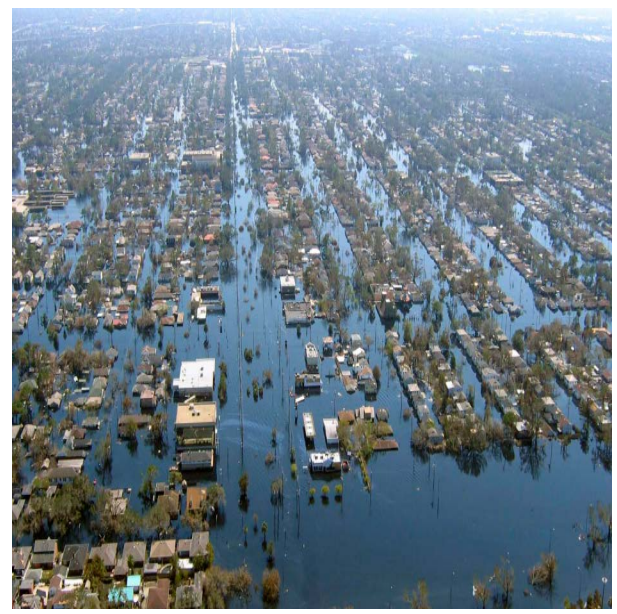

Figure 5. Inundated houses caused by Hurricane Katrina in August 2005: Image Courtesy of Public Radio International (PRI) [34].

\subsection{Demographic Analysis in the Study Area}

From 1990, 2000, 2010 and 2020 population census, Southeast Louisiana Parishes which comprised of the study area had a combined population of $1,576,127$; $1,534,433 ; 1,426,253$ and $1,638,857$ respectively (Table 3 ). Data shown in Table 3 indicates that the total population of the study area declined by $-2.65 \%$ between 1990 and 2000, and $-7.05 \%$ between 2000-2010 respectively. In the subsequent years between 2010 and 2020, the population in the area grew by $14.91 \%$. The study area experienced intense hurricane activities between 1990 and 2000 (Table 1). As a result, some of the Parishes experienced steady to moderate and negative population growths. For example, Washington, St. Tammany, Terrebonne, Plaquemines, and St. Bernard had positive growth rates of (14\%), (32.35\%), (25.35\%), (4.62\%) and (0.89\%) respectively. Others such as St. Charles posted the highest decline in population at the rate of $(-30.67 \%)$, followed by La Fourche $(-29.82 \%)$ and St. John the Baptist $(-22.88 \%)$ in that same period. Some of the parishes in the study area witnessed turbulent years during the period 2000 and 2010 because of hurricane activities such as Allison, Ivan, Katrina and Rita (Table 1). The area was significantly impacted by the activities of these Hurricanes in 2005 causing some of the population to move out of the area to other parishes. The affected Parishes whose populations decreased in number were Orleans $-27.53 \%$, St. Bernard $-43.82 \%$, Plaquemines $-6.17 \%$ and Jefferson $-4.76 \%$. The period between 2010 and 2020 has seen an impressive population growth rate of some of the parishes in the study area. Jefferson, Orleans, and Bernard which recorded negative growth rates between 2010 and 2010 showed positive increases in populations with growth rates at $3.9 \%, 11.33 \%$, and 23.72\% respectively. Furthermore, parishes such as Tangipahoa, St. John the Baptist, St. Charles, La Fourche and Terrebonne have seen the most rapid increases in population over the 2010-2020 period, at rates of (35.28\%), (25.53\%), (64.92\%), (58.11\%), and (42.48\%) respectively since 2010 . The study area's spatial distribution of population in 2020 is shown in Figure 6. 


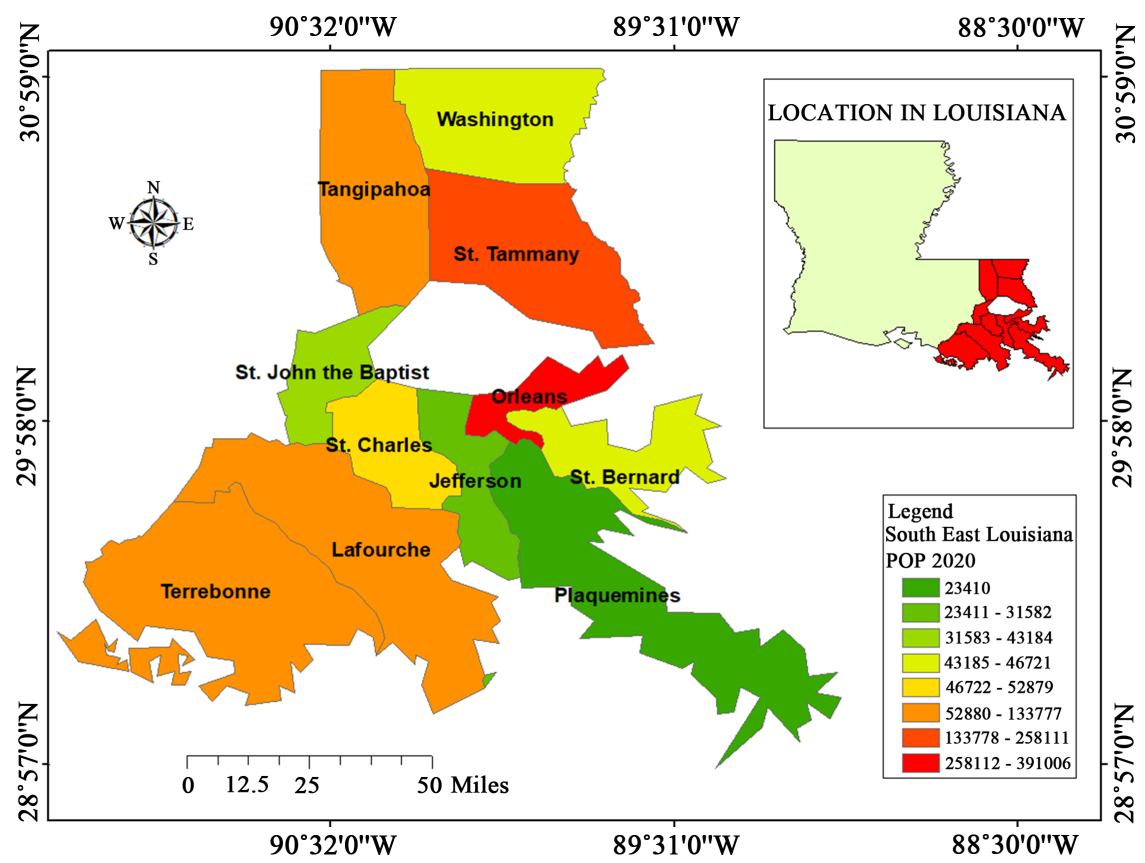

Figure 6. The 2020 population of the study area.

\subsection{Data Acquisition}

In order to identify flood-prone areas in Southeast Louisiana, a set of different spatial data was acquired. These included elevation and satellite data. Elevation data was obtained from the National Elevation Dataset (NED) produced by the United States Geological Survey (USGS) seamless data warehouse [36]. Satellite data was obtained from USGS Earth explorer website. This consisted of two pairs of Landsat Enhanced Thematic Mapper Plus (ETM+) WRS-2 satellite data acquired between November 18, 1999 and November 27, 1999 covering the eleven Southeast Louisiana parishes. The path and row of the satellite data are 22 and 39; and 21 and 39 respectively [37].

\subsection{Data Processing}

\subsubsection{Elevation Data}

Topographical information on runoff characteristics was generated using Twumasi and Asomani-Boateng [10] method. They included slope, aspect and the digital elevation model. Elevation data are invaluable for assessing and documenting flood risk and communicating detailed information. Grid interpolation TIN (triangulated irregular network) was carried from the digital elevation model (DEM) to create slope map. The slope and the DEM were classified into high and low values. The flood vulnerability area map was generated using the Boolean operation in Arc GIS Raster calculation tool. The idea of using Boolean operation is to detect areas where topography is simultaneously low slope and low elevation.

Additionally, in order to assess flood risk areas, Twumasi et al. [8] approach was used. This method employs image drape technique to visualize the land- 
scape of the study area. To do that, both images (DEM and satellite image) were re-projected and co-registered using the projection of the study area and satellite data as a base. This procedure permits overlay of both images.

\subsubsection{Satellite Data}

Landsat ETM+ images were processed using ERDAS IMAGINE 2017 image processing software. The images were imported into ERDAS as a single band and housed into ERDAS using ERDAS native file format GEOTIFF. To convert the single panchromatic bands 1 - 12 into multispectral data, ERDAS Layer Stack modules were used to group the images. This was followed by radiometric correction of all the images for variation in sun angle and atmospheric effects. Additionally, all the images were geometrically corrected to remove, haze, scan lines and speckles and referenced to the Louisiana ground-based coordinate system and Datum. Landsat ETM+ data of November 18, 1999 and November 27, 1999 were mosaicked. This was followed by a histogram equalization enhancement technique performed on all the images. Later, a shape file of the study area parishes (Washington, Tangipahoa, St. Tammany, St. John the Baptist, Orleans, St. Charles, St. Bernard, Jefferson, LaFourche, Plaquemines and Terrebonne) Shape file was imported into ERDAS, and used as ERDAS Area of Interest Tool (AOI) file to subset the ETM+ image of the study area.

\subsubsection{Image Drape}

Image Drape was performed using ERDAS IMAGINE Virtual GIS. The output image was then draped over the NED elevation data for visualization purposes with vertical exaggeration of 16 feet.

\section{Results and Discussion}

Results of elevation and satellite image processing are shown in Figures 7-10. Figure 7 shows image drape of Southeast Louisiana. The image was generated from a Landsat $1999 \mathrm{ETM}+$ satellite image draped over an elevation model produced from USGS $30 \mathrm{~m}$ elevation data downloaded from the website. In order to enhance the topographic expression, the image was exaggerated 3-times in height. Colors of the scene were enhanced by use of a combination of visible red, green, and blue wavelengths and infrared bands with RGB 4, 3, 2. Figure 8 shows the classified image of DEM of the study area. Figure 8 shows classified DEM of Southeast Louisiana. Areas with the low elevation below sea level are shown in the dark and light green color. Figure 9 displays the flow direction of the elevation. Flow direction determines which direction water will flow in a given cell. Figure 10 shows elevation aspect of the study area. Flat surfaces have no aspect and are given a value of -1 . If the highest cell value is located at the top-left of the window ("top" being due north) and the lowest value is at the bottom-right, it can be assumed that the aspect is southeast. Figure 11 represents 3D Triangular Irregular Network (TIN) elevation showing both low and higher elevation of the study area. Figure 12 shows the census block of the study area. Results displayed 


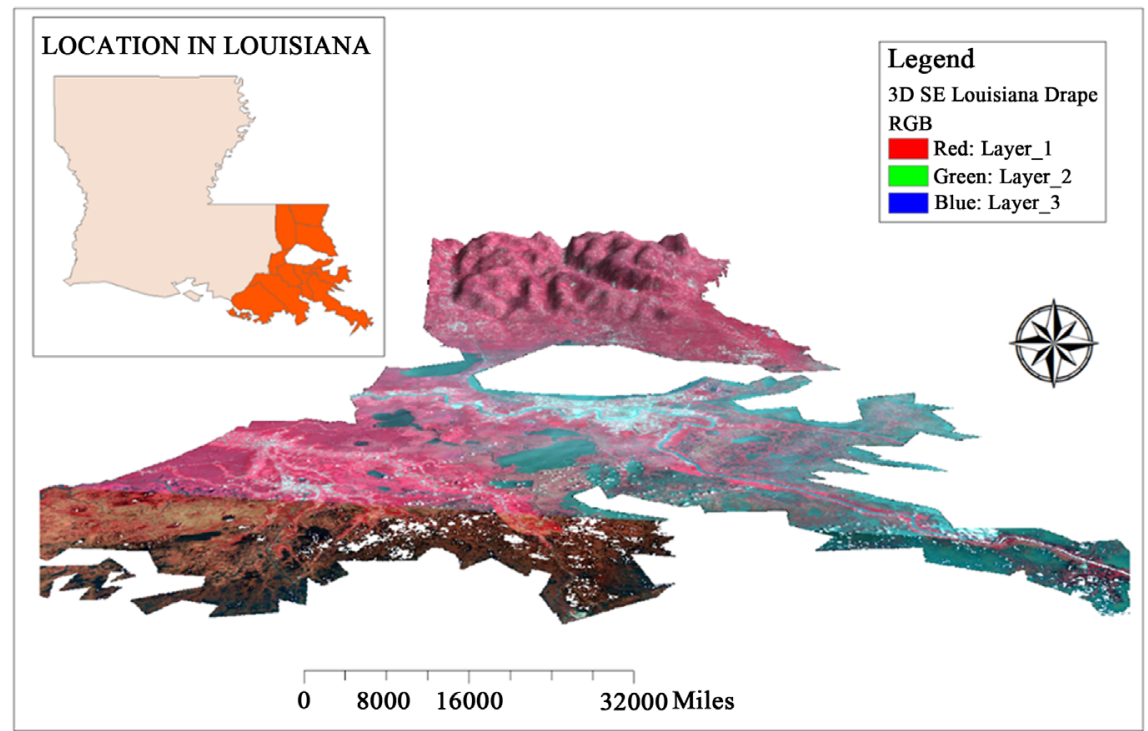

Figure 7. Image drape of Southeast Louisiana. From the image, Southeast Louisiana appears in the foreground of this perspective view generated from a Landsat satellite image and elevation data from USGS.

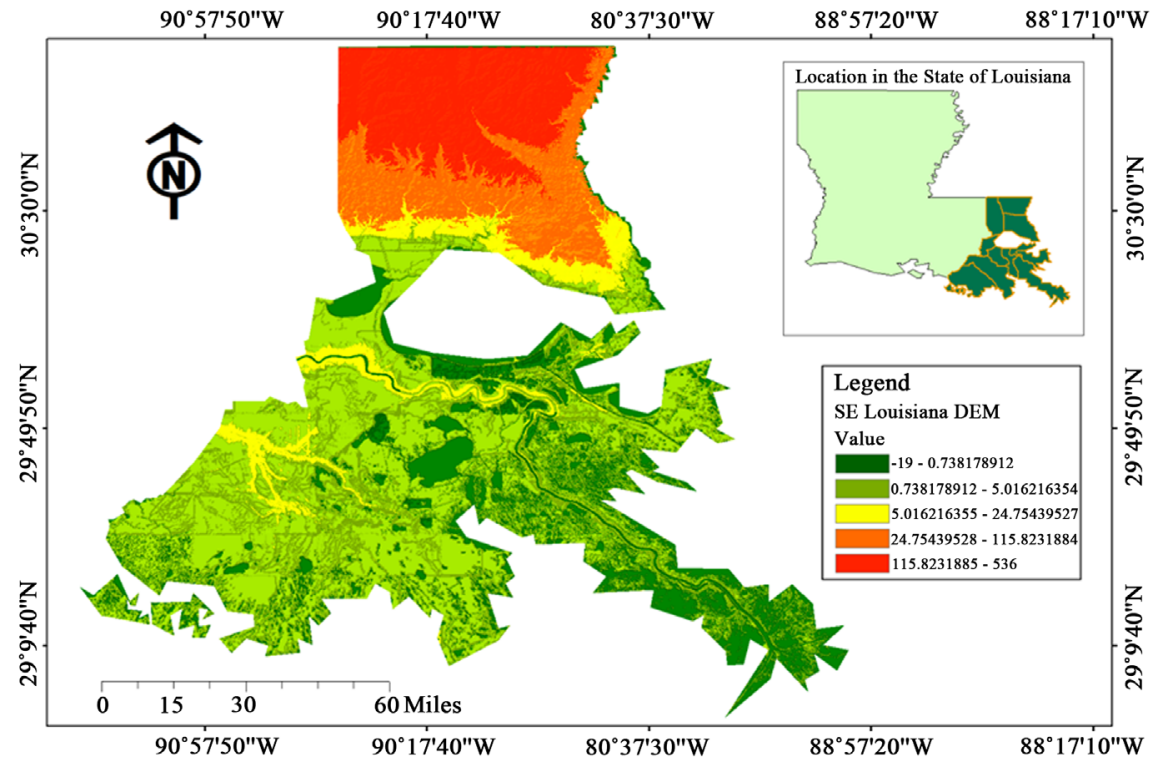

Figure 8. Classified DEM of southeast Louisiana.

in Figures 7-11 have shown that, the population of most of the study area lives in low-lying coastal urban centers except Washington, Tangipahoa and St. Tammany which are in the upper elevations. Low-lying areas especially in the study area could experience, increased flooding activities and sea level rise if hurricanes and severe storms became stronger. The rise in sea level could lead to submergence. This could also damage substantially coastal infrastructure.

This study can enhance decision-making as a support tool in flood disaster management by showing the exact locations of flood risk areas in the parishes. For example, one of the things environmental managers would regularly need, is 


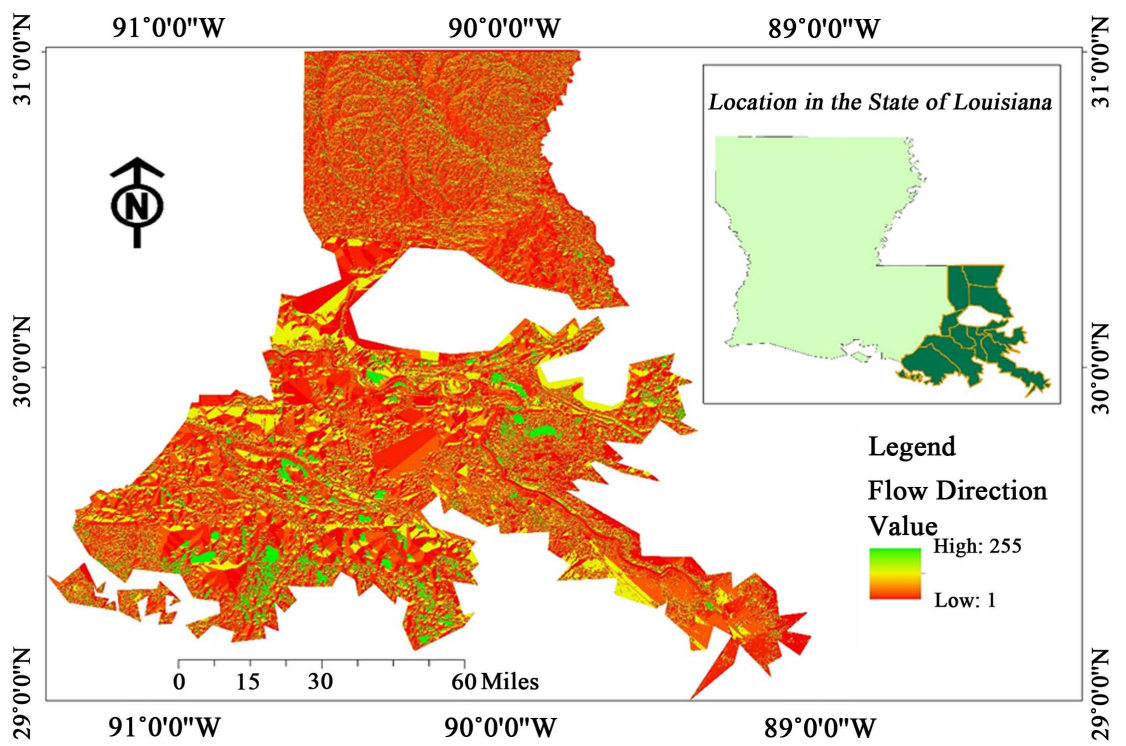

Figure 9. Flow direction of the elevation in the study area.

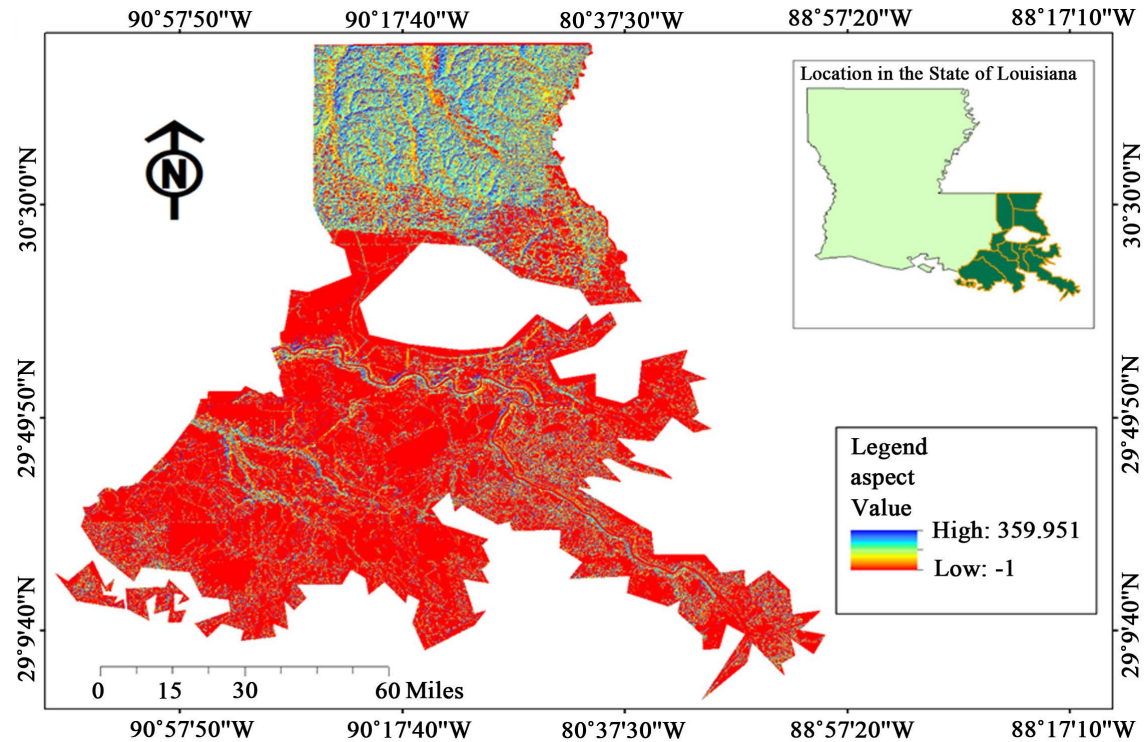

Figure 10. Aspect of the elevation.

to access simulations of complex spatial data pictures in simplified ways to optimize quick assessments of areas at which the damage is going to be concentrated during flooding disasters and inclement weather debacles. Access to such a tool can improve the capability of planners in the formulation of effective procedures to follow with regard to location of the damage, evacuation plans to help emergency service workers and first responders to direct the population at risk in the most efficient manner to safer grounds during crisis [8].

\section{Policy Options and Conclusion}

With a total population of $1,638,857$ in 2020, which is almost a third of the State's population (Table 3, Figure 6), there is the need for an appropriate policy 


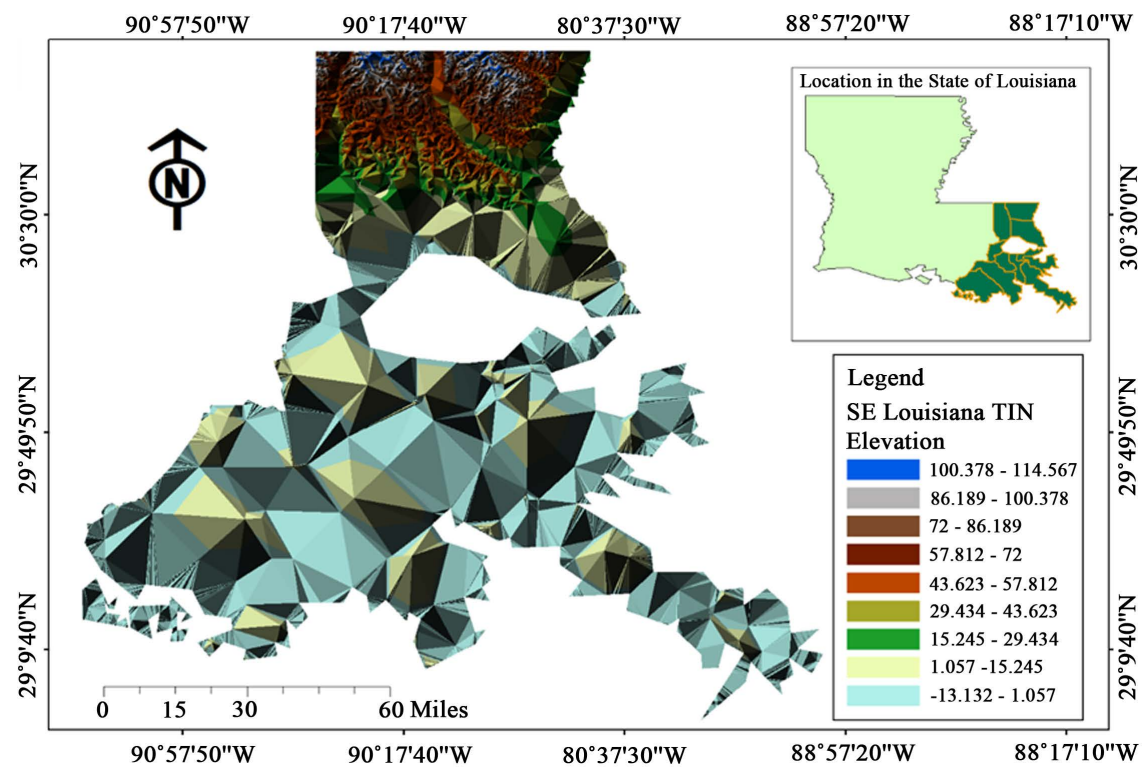

Figure 11. Southeast Louisiana TIN elevation.

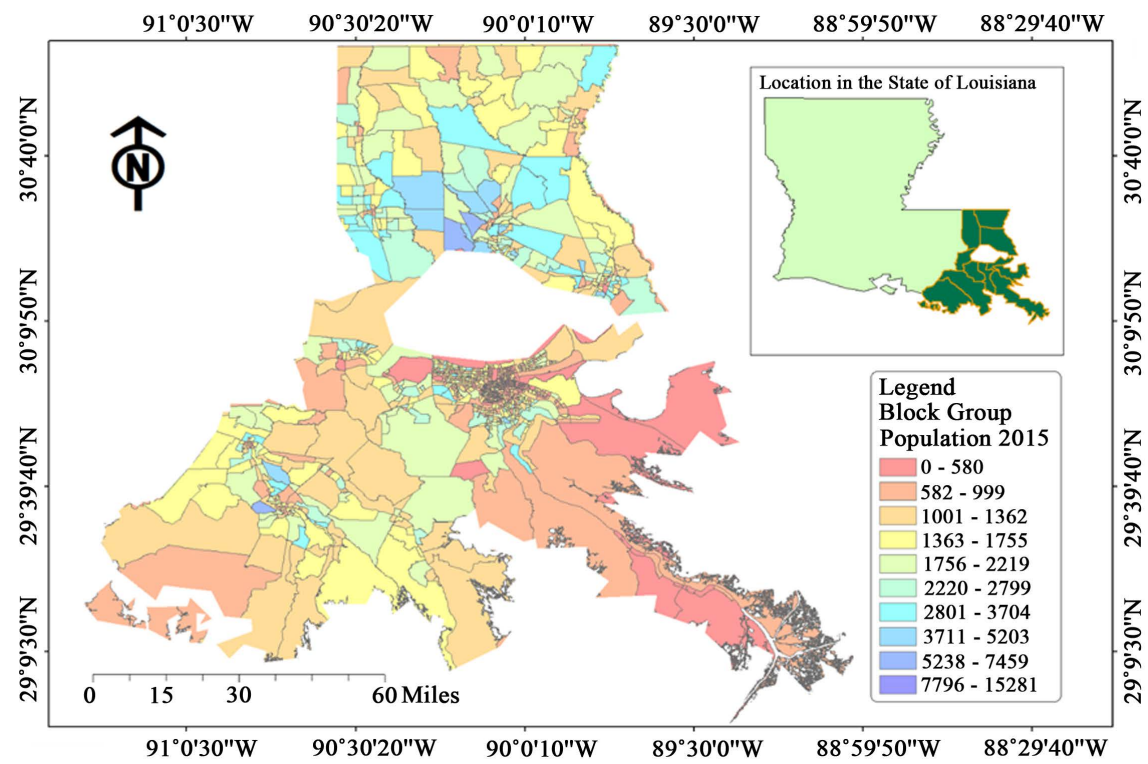

Figure 12. Study area census block group.

that focuses on dealing with a flooding or other coastal-zone environmental crisis. Results of GIS and remote sensing imagery shown in this study can serve as a powerful motivating factor instructional and sensitizing tool for the population at large, which may not appreciate the dangers experienced in the coastal areas of Southeast Louisiana as a result of overpopulation. There is also the need to design and build a comprehensive Regional Information Systems (RIS) in the form of periodic inventorying, monitoring and evaluation with full support of the governments in the study area. RIS would entail combining remote sensing data, climate data, field survey data, national and local-level weather forecast, and hydrological data including information on the river flow into one system. 
Table 3. Population of the Southeast Louisiana Parishes from 1990-2010 [35].

\begin{tabular}{cccccccc}
\hline & & & & & $\%$ Change & \% Change & \% Change \\
Parish & 1990 & 2000 & 2010 & 2020 & $\begin{array}{c}(1990-2000) \\
\%\end{array}$ & $\begin{array}{c}(2000-2010) \\
(2010-2020)\end{array}$ \\
\hline Washington & 43,185 & 49,566 & 51,133 & 46,582 & 14.77 & 3.16 & 8.9 \\
Tangipahoa & 85,709 & 83,302 & 98,890 & 133,777 & -2.80 & 18.71 & 35.28 \\
St. Tammany & 144,508 & 191,268 & 237,867 & 258,111 & 32.35 & 24.36 & 8.51 \\
St. John the & 39,996 & 30,841 & 34,402 & 43,184 & -22.88 & 11.54 & 25.53 \\
Baptist & & & & & & & \\
Orleans & 496,938 & 484,674 & 351,222 & 391,006 & -2.46 & -27.53 & 11.33 \\
St. Charles & 42,437 & 29,418 & 32,064 & 52,879 & -30.67 & 8.99 & 64.92 \\
St. Bernard & 66,631 & 67,229 & 37,764 & 46,721 & 0.89 & -43.82 & 23.72 \\
LaFourche & 85,860 & 60,255 & 62,054 & 98,115 & -29.82 & 29.85 & 58.11 \\
Plaquemines & 25,575 & 26,757 & 25,106 & 23,410 & 4.62 & -6.17 & -6.76 \\
Terrebonne & 96,982 & 72,392 & 77,923 & 111,021 & 25.35 & 7.64 & 42.48 \\
Jefferson & 448,306 & 438,731 & 417,828 & 434,051 & -2.13 & -4.76 & 3.9 \\
Total & $1,576,127$ & $1,534,433$ & $1,426,253$ & $1,638,857$ & -2.65 & -7.05 & 14.91 \\
\hline
\end{tabular}

Developing such a system would offer the decision makers access to the appropriate temporal-spatial data for monitoring the pressures mounted on the areas' socio-economic systems and ecosystems by seasonal floods. Such a tool could act as an effective decision support system in order to keep development in harmony with environmental sustainability.

\section{Conflicts of Interest}

The authors declare no conflicts of interest regarding the publication of this paper.

\section{References}

[1] Wikipedia (2019) World Conference on Disaster Risk Reduction. https://en.wikipedia.org/wiki/World_Conference_on_Disaster_Risk_Reduction

[2] UN World Conference on Disaster Risk Reduction http://www.un.org/sustainabledevelopment/un-world-conference-on-disaster-risk-r eduction/

[3] Zabarenko, D. (2013) U.S. Spent \$62 Billion on Disaster Relief in Fiscal 2011 and 2012. https://www.reuters.com/article/us-usa-disaster-spending-idusbre98alah20130911

[4] NOAA (2018) Flood Damage Data. NOAA, U.S. Department of Commerce. http://www.nws.noaa.gov/hic/

[5] Brittain, B. (2018) Weather Disasters Cost U.S. Record \$306 Billion in 2017: NOAA. https://www.reuters.com/article/us-usa-climatechange/weather-disasters-cost-u-s-r ecord-306-billion-in-2017-noaa-idUSKBN1EX1XC

[6] NOAA (2018) U.S. Hit with 3 Billion-Dollar Disasters in First 3 Months of 2018. 
NOAA, U.S. Department of Commerce.

http://www.noaa.gov/news/us-hit-with-3-billion-dollar-disasters-in-first-3-monthsof-2018

[7] Merem, E.C., Twumasi, Y.A., Foster, D., Richardson, C. and Yeramilli, S. (2012) Using GIS and Climate Risks Information to Analyze the Vulnerability of Coastal Counties in Louisiana and Mississippi. Resources and Environment, 2, 1-16. https://doi.org/10.5923/j.re.20120201.01

[8] Twumasi, Y.A., Merem, E.C. and Ayala-Silva, T. (2016) Coupling GIS and Remote Sensing Techniques for Coastal Zone Disaster Management: The Case of Southern Mississippi. Geoenvironmental Disasters, 3, 1-9. https://doi.org/10.1186/s40677-016-0056-7

[9] Mittal, A. (2018) Disaster Management Using Remote Sensing Technology. Sky Map Global. https://skymapglobal.com/disaster-management-remote-sensing/

[10] Twumasi, Y.A. and Asomani-Boateng, R. (2002) Mapping Seasonal Hazards for Flood Management in Accra, Ghana Using GIS. Proceedings of the IEEE International Geoscience and Remote Sensing Symposium (IGARSS) Conference, Westin Harbour Castle, Toronto, Canada, Institute of Electrical and Electronics Engineers Inc., Piscataway, NJ, 24-28 June 2002. https://doi.org/10.1109/IGARSS.2002.1026807

[11] Twumasi, Y.A., Coleman, T.L. and Manu, A. (2003) Integrated Resource Databases for Coastal Zone Management of Metropolitan Accra. Proceedings of the Annual Convention and Exhibition of the American Society for the Photogrammetry and Remote Sensing (ACSM-ASPRS), Bethesda, MD, 206-214. http://www.asprs.org/a/conference-archive/alaska2003/proceedings.shtml

[12] Twumasi, Y.A., Merem, E.C., Ayala-Silva, T., Osei, A., Petja, B.M. and Alexander, K. (2017) Techniques of Remote Sensing and GIS as Tools for Visualizing Impact of Climate Change-Induced Flood in Southern African Region. American Journal of Climate Change, 6, 306-327. https://doi.org/10.4236/ajcc.2017.62016

[13] Cox, D. and James, K. (2009) City of Davenport Uses 3D Visualization to Prepare for Flooding Environmental Observer, Winter. http://www.esri.com/library/reprints/pdfs/envobsv_davenport.pdf

[14] Ozkan, S.P. and Tarhan, C. (2016) Detection of Flood Hazard in Urban Areas Using GIS: Izmir Case. Procedia Technology, 22, 373-381. https://doi.org/10.1016/j.protcy.2016.01.026

[15] Klemas, V. (2015) Remote Sensing of Floods and Flood-Prone Areas: An Overview. Journal of Coastal Research, 31, 1005-1013. https://doi.org/10.2112/JCOASTRES-D-14-00160.1

[16] Udani, P.M. and Mathur, D.K. (2016) Flood Hazard Vulnerability Mapping Using Remote Sensing \& GIS: A Case Study along the Villages of Anand Taluka. Advances in Applied Science Research, 7, 214-221.

[17] Purnawali, S.H., Hariyanto, T., Pratomo, D.G. and Hidayati, N. (2017) Flood Vulnerability Analysis Using Remote Sensing and GIS: A Case Study of Sidoarjo Regency. Regional Conference in Civil Engineering (RCCE) 568 The Third International Conference on Civil Engineering Research (ICCER), Surabaya, Indonesia, 1-2 August 2017. https://doi.org/10.12962/j23546026.y2017i6.3305

[18] Rimba, A.B., Setiawati, M.D., Sambah, A.B. and Miura, F. (2017) Physical Flood Vulnerability Mapping Applying Geospatial Techniques in Okazaki City, Aichi Prefecture, Japan. Urban Science, 1, 7. https://doi.org/10.3390/urbansci1010007

[19] Ahmed, C.F. and Kranthi, N. (2018) Flood Vulnerability Assessment Using Geospa- 
tial Techniques: Chennai, India. Indian Journal of Science and Technology, 11, Article ID: 110831. https://doi.org/10.17485/ijst/2018/v11i6/110831

[20] Dano, U.L., Balogun, A.-L., Matori, A.N., Yusouf, K., Abubakar, I.R., Mohamed, M.A.S., Aina, Y.A. and Pradhan, B. (2019) Flood Susceptibility Mapping Using GIS-Based Analytic Network Process: A Case Study of Perlis, Malaysia. Water, 11, 615. https://doi.org/10.3390/w11030615

[21] Isma'il, M. and Saanyol, I.O. (2013) Application of Remote Sensing (RS) and Geographic Information System (GIS) in Flood Vulnerability Mapping: Case Study of River Kaduna. International Journal of Geomatics and Geosciences, 3, 618-627.

[22] Lanza, I. and Conti, M. (1994) Remote Sensing and GIS: Potential Application for Flood Hazard Forecasting. Proceedings of the EGIS/MARI 1994 Conference, 2, 1835-1844.

[23] Dang, A.T.N. and Kumar, L. (2017) Application of Remote Sensing and GIS-Based Hydrological Modelling for Flood Risk Analysis: A Case Study of District 8, Ho Chi Minh City, Vietnam. Geomatics, Natural Hazards and Risk, 8, 1792-1811. https://doi.org/10.1080/19475705.2017.1388853

[24] Kosovich, J.J. (2008) State of Louisiana-Highlighting Low-Lying Areas Derived from USGS Digital Elevation Data. Scientific Investigations Map 3049.Version 1.0. https://pubs.usgs.gov/sim/3049/downloads/SIM3049.pdf https://doi.org/10.3133/sim3049

[25] U.S. Department of Commerce, National Oceanic and Atmospheric Administration (NOAA) (2019) Tropical Cyclone Annual Summaries 1872-2006 (Monthly Weather Review). https://www.nhc.noaa.gov/data/\#monthly

[26] Environmental Defense Fund (EDF) (2010) Hurricanes and Climate Change. Louisiana's Coast: What's at Stake. New York, 1-2.

[27] U.S. Department of Commerce, National Oceanic and Atmospheric Administration (NOAA) (2007) Monthly Weather Review-Annual Summaries of North Atlantic Storms, 1872-2011. NOAA Miami Regional Library. https://www.aoml.noaa.gov/general/lib/lib1/nhclib/mwreviews.html

[28] U.S. Department of Commerce, National Oceanic and Atmospheric Administration (NOAA) (2020) National Hurricane Center (NHC) and Central Pacific Hurricane Center Data Archive. https://www.nhc.noaa.gov/data/

[29] Steward, S. (2014) 2012 Atlantic Hurricane Season. National Hurricane Center Annual Summary. https://www.nhc.noaa.gov/data/tcr/summary_atlc_2012.pdf

[30] The Associated Press (2019) Tropical Storm Barry Brings Heavy Rains, Floods to Louisiana CBC News. https://www.cbc.ca/news/world/louisiana-barry-saturday-1.5210966

[31] Maxouris, C. (2019) Barry Brings Back Traumatic Memories for Katrina Survivors. https://www.cnn.com/us/live-news/tropical-storm-barry-saturday-2019-intl/h_1050 32c3685d071a4601adba56a14f2e

[32] Mitchell, J.D. (2019) When the Mississippi Is Swollen, Will Putting Comite River Diversion Waters into It Be Harmful?

https://www.theadvocate.com/baton_rouge/news/article_4fdb1806-afd5-11e9-be833f71c62e1942.html

[33] Graff, A. (2019) Photos Show Eerie Scene as Torrential Rains Flood New Orleans. San Francisco Gate (SFGATE).

https://www.sfgate.com/weather/article/flooding-new-orleans-pictures-video-frenc h-quarter-14085235.php\#photo-17836494 
[34] Wernick, A. (2015) New Orleans Is Still Vulnerable to Another Big Storm. Public Radio International (PRI).

https://www.pri.org/stories/2015-09-14/new-orleans-still-vulnerable-another-big-st orm

[35] World Population Review (2019) Population of Counties in Louisiana (2020). http://worldpopulationreview.com/us-counties/la/

[36] U.S. Geological Survey (2019) The National Map. http://nationalmap.gov/viewer.html

[37] U.S. Geological Survey (2019) EarthExplorer-Home. Satellite Data. https://earthexplorer.usgs.gov/ 